University of Nebraska - Lincoln

DigitalCommons@University of Nebraska - Lincoln

Faculty Publications in Food Science and Technology

Food Science and Technology Department

2007

\title{
Corroborative Study on Maize Quality, Dry-Milling and Wet-Milling Properties of Selected Maize Hybrids
}

\author{
Kyung-Min Lee \\ Texas A\&M University, kml@otsc.tamu.edu \\ Timothy J. Herrman \\ Texas A\&M University, tjh@otsc.tamu.edu \\ Lloyd Rooney \\ Texas A\&M University, Irooney@tamu.edu \\ David S. Jackson \\ University of Nebraska-Lincoln, djackson1@unl.edu \\ Jane Lingenfelser \\ Kansas State University, jling@ksu.edu \\ See next page for additional authors
}

Follow this and additional works at: https://digitalcommons.unl.edu/foodsciefacpub

Part of the Food Science Commons

Lee, Kyung-Min; Herrman, Timothy J.; Rooney, Lloyd; Jackson, David S.; Lingenfelser, Jane; Rausch, Kent D.; McKinney, John; liams, Chris; Byrum, Linda; Hurburgh, Charles R. Jr.; Johnson, Lawrence A.; and Fox, Steven R., "Corroborative Study on Maize Quality, Dry-Milling and Wet-Milling Properties of Selected Maize Hybrids" (2007). Faculty Publications in Food Science and Technology. 117.

https://digitalcommons.unl.edu/foodsciefacpub/117

This Article is brought to you for free and open access by the Food Science and Technology Department at DigitalCommons@University of Nebraska - Lincoln. It has been accepted for inclusion in Faculty Publications in Food Science and Technology by an authorized administrator of DigitalCommons@University of Nebraska - Lincoln. 


\section{Authors}

Kyung-Min Lee, Timothy J. Herrman, Lloyd Rooney, David S. Jackson, Jane Lingenfelser, Kent D. Rausch, John McKinney, Chris liams, Linda Byrum, Charles R. Hurburgh Jr., Lawrence A. Johnson, and Steven R. Fox 


\title{
Corroborative Study on Maize Quality, Dry-Milling and Wet-Milling Properties of Selected Maize Hybrids
}

\author{
Kyung-Min Lee, ${ }^{1}$ Timothy J. Herrman, ${ }^{1}$ Lloyd Rooney, ${ }^{2}$ David S. Jackson, ${ }^{3}$ \\ Jane Lingenfelser, ${ }^{4}$ Kent D. Rausch, ${ }^{5}$ John McKinney, ${ }^{5}$ Chris Iiams, ${ }^{6}$ Linda Byrum, ${ }^{6}$ \\ Charles R. Hurburgh, Jr., ${ }^{7}$ Lawrence A. Johnson, ${ }^{8}$ and Steven R. Fox ${ }^{8}$
}

1. Office of the Texas State Chemist, Texas Agricultural Experiment Station, Texas A\&M University, College Station, Texas 77841

2. Soil and Crop Sciences Department, Texas A\&M University, College Station, Texas 77843

3. Department of Food Science and Technology, University of Nebraska, Lincoln, Nebraska 68583

4. Department of Agronomy, Kansas State University, Manhattan, Kansas 66506

5. Department of Agricultural and Biological Engineering, University of Illinois, Urbana, Illinois 61801

6. Pioneer Hi-Bred International, Inc., Urbandale, Iowa 50322

7. Department of Agricultural and Biosystems Engineering, Iowa State University, Ames, Iowa 50011

8. Center for Crops Utilization Research, Iowa State University, Ames, Iowa 50011

Corresponding author - T. J. Herrman, tel 979 845-1121, fax 979 845-1389, email tjh@otsc.tamu.edu

\begin{abstract}
A corroborative study was conducted on the maize quality properties of test weight, pycnometer density, tangential abrasive dehulling device (TADD), time-to-grind on the Stenvert hardness tester (SHT), 100-kernel weight, kernel size distribution, and proximate composition as well as maize dry- and wet-millability by six participating laboratories. Suggested operating procedures were given to compare their measurements and provide the variance structure within and between laboratories and hybrids. Partial correlation coefficient among maize quality properties varied among laboratories. The repeatability and reproducibility precision values were acceptably low for the physical quality tests, except for TADD and SHT time-to-grind measurements. The yields of dry- and wet-milled products and their correlation with maize quality properties were dependent on the collaborating laboratory. This paper highlights the importance of laboratory variation when considering which maize hybrids are best suited for dry-milling and wet-milling.
\end{abstract}

Keywords: maize quality property, variation, outlier, repeatability, reproducibility, dry-milling, wet-milling

\section{Introduction}

Maize quality is determined by the combined effect of cellular structure and physical and biochemical properties of components within grain (1). Variations in maize quality occur because of various estimable and inestimable factors, including environment, cultural practice, genetics, growing and postharvesting conditions, kernel chemical composition, and so forth (2-8).

Physical measurements used to characterize maize hardness measure biochemical and anatomical characteristics that determine end-use properties $(4,6,9,10)$. Harder maize kernels exhibit improved performance as compared to softer maize kernels during storage, handling, transportation, alkaline cooking, and dry-milling, whereas softer kernels perform better in wet-milling (11-13). A variety of physical, spectroscopic, and biochemical techniques developed over the past several decades better define maize quality and hardness in faster, simpler, and more reliable ways. Although such techniques are used to evaluate quality and hardness-associated properties, correlations between quality properties and enduse processing performance vary from laboratory to laboratory $(6,14-16)$.

A classification and segregation of maize kernels best suited for particular end-use processing, such as dry- and wetmilling and alkaline processing, might maximize grain values for producers, marketers, and processors; however, little standardization and instruction for physical and analytical tests seem to limit the development of a standardized set of criteria to classify and segregate grain having different intrinsic enduse values.

This study enabled us to compare collaborators' measurements of maize quality and end-use processing properties, providing information about the variance structure of grain 
properties within and between laboratories and hybrids. Furthermore, the study will assist in establishing universal standard testing procedures and in correctly interpreting data, thereby supporting future researchers and industry partners.

\section{Materials and Methods}

Maize Samples. Forty maize hybrid samples for maize, representing a range of physical, compositional, and processing properties, were selected from more than 500 maize hybrids of a broad genetic background and known pedigree planted at different locations in Illinois, Indiana, Iowa, Kansas, Missouri, and Nebraska during 2003 and 2004. This set of genetically and environmentally diverse maize hybrids was used in another study establishing the relationship between maize quality properties and end-use processing (17). To further reduce the number of maize samples for this study, four clusters consisting of hybrids with analogous compositional and physical properties were created using multivariate statistical techniques on the basis of physical properties (test weight, kernel distribution, time-to-grind on Stenvert hardness tester (SHT), tangential abrasive dehulling device (TADD), pycnometer density, and 100-kernel weight) and near-infrared reflectance (NIR) or near-infrared transmittance (NIT) proximate composition (protein, oil, and starch contents) (18). Considering growing location of maize hybrids within a cluster, two or three hybrids were selected from each cluster, making 11 total samples. The samples were cleaned with the MCI Kicker dockage tester (Mid-Continent Industries, Inc., Newton, KS) to minimize the influence of foreign materials and broken kernels on the measurements.

Sample Preparation and Distribution. Each maize hybrid stored in a cold room $\left(4^{\circ} \mathrm{C}\right)$ was thoroughly mixed and quartered twice, placed into airtight plastic bags, and distributed to participants. Each hybrid sample was blind-duplicated and randomly coded. Upon receiving samples, the coordinator of each laboratory was requested to store their samples at approximately $4^{\circ} \mathrm{C}$ until analyzed, minimizing compositional and grain quality changes.

Corroborative Study. The corroborative study was carried out by six participating university and industry laboratories according to collaborative study guidelines $(19,20)$ with slight modification. Eleven blind-duplicated maize hybrid samples were sent to each laboratory with suggested standard operating procedures. Contrary to other collaborative studies, most participants in the present study were already familiar with current maize quality tests as well as processing tests; however, at an initial stage, collaborators were sent three samples to judge whether the study could proceed.

Compositional and Physical Properties. Test Weight. Test weight $(\mathrm{kg} / \mathrm{hl})$ was measured according to the United States Department of Agriculture's (USDA's) Federal Grain Inspection Service's Protocol (21). Prior to the determination, sample equilibration to the desired moisture content (about 15\%) was advised for collaborators.

Pycnometer Density (Kernel Density). A standard operating procedure for pycnometer density $\left(\mathrm{g} / \mathrm{cm}^{3}\right)$ determination as outlined by Pomeranz et al. (3) is based on the displacement of helium gas. Pycnometers used in the study were manufactured by Quantachrome Instruments (Boynton Beach, FL) and Beckman Instruments (Fullerton, CA). In air-comparison pycnometer density, kernel density is determined by measuring the weight of a given volume of sound kernels.

Tangential Abrasive Dehulling Device (TADD). The TADD (Venables Machine Works LTD, Saskatoon, Saskatchewan, Canada) index was computed as the percentage of remaining kernel weight after abrasion of a $40-\mathrm{g}$ maize sample for $10 \mathrm{~min}$ while the abraded material was simultaneously suctioned off using the vacuum aspirating device (22).

Time-to-grind using a Stenvert Hardness Tester. The time (sec) required to grind $20 \mathrm{~g}$ of a maize sample by the Stenvert microhammermill test (Glenmills Model V with a 2-mm screen) run at a noload speed of 3,600 rpm with the supplied tachometer (Ika-Tron DZM 1, Janke and Kunkel GmbH and Co. KG-IKA-Labortechnik, Staufen, Germany) was measured as described by Pomeranz et al. (4).

100-Kernel Weight. For 100-kernel weight (g), moisture content was determined as a first step by approved method 44-15A (23).
A $200 \mathrm{~g}$ sample of sound maize kernels was placed in a vibratory kernel counter to collect 100 kernels. In some laboratories, randomly selected 100 intact kernels were used for the determination of 100-kernel weight. The 100-kernel weight was adjusted to $15 \%$ moisture content using equations.

Kernel Size Distribution. Kernel size distribution was expressed as the percentage of the maize sample over a grain dockage sieve with $7.94 \mathrm{~mm}\left(20 / 64^{\prime \prime}\right)$ diameter round holes for a $250 \mathrm{~g}$ sample.

NIR/NIT Proximate Composition. Proximate composition (oil, protein, starch, and moisture contents) was estimated by using different NIR or NIT models (Infratec Model 1229, Foss Tecator, Hoganas, Sweden; Grainspec, Multispec Ltd., Wheldrake, NY; Infratec 1241 Grain Analyzer, Foss Tecator, Eden Prairie, MN) that were calibrated against wet chemical methods. All values were reported as dry $(\mathrm{db})$ or wet $(\mathrm{wb})$ basis percentages. The reported values from participating laboratories were uniformly adjusted to $15 \%$ moisture basis. A copy of the calibration curve was not requested from collaborators for the final evaluation of the data because some of the collaborators were disinclined to circulate it.

Processing Test Procedures. Dry-milling. For the corroborative study on dry-milling characteristics, a total of 22 maize samples (11 blind-duplicated maize hybrids) were sent to two laboratories that were using different milling procedures.

In Laboratory 1, $1000 \mathrm{~g}$ of maize was tempered to increase moisture from 15 to $23.5 \% \mathrm{wb}$ for $18 \mathrm{~min}$ at room temperature. Tempered samples were degerminated using a horizontal drum degermer. Thereafter, the degermed maize was conditioned in a convection oven at $49{ }^{\circ} \mathrm{C}$ for $2 \mathrm{~h}$. All stocks produced by dry-milling were screened for 1.5 min with a box sifter (Model 130-11, Great Western Mfg., Leavenworth, KS). The degermer stock was screened with a 5 -mesh sieve ( $4.0 \mathrm{~mm}$ openings) after conditioning. The fraction remaining over and passing through the sieve was fractionated using a small roller mill (Allis Chalmers, Appelton, WI), followed by a 10 -mesh screen (1.68-mm openings). The 10-mesh screen overs and thrus from +5 and -5 milling streams were separated into different dry-milled fractions via a 24-mesh screen $(0.707-\mathrm{mm}$ openings) and a small aspirator (Model 6DT4, Kice Metal Products, Wichita, KS) as outlined by Singh et al. (24). Product yields were expressed as a proportion of the original sample (g/100 g db).

In a laboratory dry-milling procedure used by Laboratory 2 , a cleaned $1000 \mathrm{~g}$ sample was tempered to $16 \%$ moisture for $30 \mathrm{~min}$ and was second-tempered to $18 \%$ moisture for $15 \mathrm{~min}$. The tempered sample was milled using Allis Chalmers experimental roll stands yielding low-fat grits. The dry-milling procedure used in this laboratory was based on the design of Lee et al. (17). The product yields were expressed as percentages of the total drymilled fractions.

Differences between the two dry-milling procedures were noticed in several processing steps, dry-milled fractions, and their compositions. Laboratory 1 used a short and single-stage tempering step to produce large grits, small grits, fines, germ, and pericarp fractions. Meanwhile, Laboratory 2 used a two-stage and lower moisture tempering to separate a kernel into large grits, small grits, meal, cones, flour, and feed fractions. Germ fractions were released under higher moisture tempering with a drum degerminator in Laboratory 1, whereas the dry-milling procedure in Laboratory 2 degerminated corn without using a degerminator. According to previous works, fat content of grit fractions was a little higher $(>1.0 \%)$ in Laboratory 1 than in Laboratory $2(<1.0 \%)$. Low reproducibility standard deviations $(1-2 \%)$ of the dry-milling procedure have been reported from both laboratories.

Wet-milling. Three laboratories participated in the corroborative study on wet-milling characteristics. Wet-milling procedures used in the present study appeared to have been developed and modified from the same or similar procedures published previously.

The $100 \mathrm{~g}$ laboratory wet-milling procedure developed by Eckhoff et al. (25) was used in Laboratory 1 . In this wet-milling procedure, the drained maize after steeping was ground with a blender equipped with a blunt blade to recover germ and coarse fiber on a 7 -mesh sieve ( $2.80 \mathrm{~mm}$ openings). For the recovery of fine fiber, the slurry passing through the sieve was reground, transferred, and washed on a 200 -mesh sieve $(0.075 \mathrm{~mm}$ openings). The starch was separated from the gluten fraction using starch tables at the 
pumping rate of $50-52 \mathrm{~mL} / \mathrm{min}$ after adjusting the specific gravity of the starch-gluten containing slurry to 1.040-1.045. The gluten fraction was recovered using a vacuum filter and air-oven drying. This collaborating laboratory reported product yields expressed as percentages of the original sample dry weights on a dry basis.

In Laboratory 2, $150 \mathrm{~g}$ of maize sample was batch-steeped in a steep solution containing $0.15 \%$ sulfur dioxide $\left(\mathrm{SO}_{2}\right)$ and $0.47 \%$ lactic acid at $52{ }^{\circ} \mathrm{C}$ for $48 \mathrm{~h}$. The drained grains were coarsely ground in distilled water with a Waring type blender (Waring Product Division, New Hartford, CT) equipped with a blunt blade. Floating germs on the slurry surface were removed using a 16-mesh sieve (1.18 $\mathrm{mm}$ openings). The degermed slurry and germ wash water were finely ground in a blender jar with reversed blades. The slurry was transferred into 40 -mesh sieve (0.425 mm openings) and 230 -mesh sieve $(0.063 \mathrm{~mm}$ openings) screens and spray-washed to separate bran and fines, respectively. The remaining starch-protein slurry was collected and allowed to settle overnight. The slurry was decanted and adjusted to $8^{\circ}$ Baume. The adjusted slurry was pumped at a rate of $150 \mathrm{~mL} / \mathrm{min}$ onto a prewetted $15.36 \mathrm{~cm} \times 3.05 \mathrm{~m}$ aluminum trough set at $0.75 \%$ slope. The recovered starch was washed with decanted supernatant and then rinsed with distilled water. The starch was air-dried for at least $1 \mathrm{~h}$, followed by oven-drying overnight. The yields of all wet-milled products were determined on a dry basis. Other details of this procedure were outlined by Wehling et al (26).

In Laboratory 3, $100 \mathrm{~g}$ of maize was placed in a steep solution containing $0.2 \% \mathrm{SO}_{2}$ and $0.5 \%$ lactic acid in a water bath set at 50 ${ }^{\circ} \mathrm{C}$ for $40 \mathrm{~h}$. The steeped maize was strained on a 7-mesh sieve (2.80 mm openings). The steep solids were recovered by drying the entire steep water. The steeped maize was ground with water in a Waring blender equipped with blunt blades. The coarsely ground slurry was transferred into a 7-mesh sieve $(2.8 \mathrm{~mm}$ openings) and dispersed with a spatula to strain the slurry. The sieve containing the strained germ and coarse fiber fraction was placed on a bucket containing water in a sieve shaker and was washed with water. The strained germ and coarse fiber fraction was dried directly on the sieve in a forced-air oven and was separated by a Carter-Day Aspirator (Carter Day International, Inc., Minneapolis, MN). The combined wash water and the degermed slurry were finely ground in a Waring blender. The coarse fiber fraction retained on a 50 -mesh sieve ( $0.30 \mathrm{~mm}$ openings) was removed. The washed coarse fiber fraction scraped off the sieve was dried in a forced-air oven. The underflow containing fine fiber and mill starch was transferred into a 200 -mesh sieve $(0.075 \mathrm{~mm}$ openings) placed over a snugly fitted bucket. The same straining and washing procedures for the coarse fiber fraction were carried out for the fine fiber. The recovered fine fiber fraction was dried in a forced-air oven. The specific gravity of the millstarch slurry was adjusted to 1.04 with decant water. The adjusted slurry was pumped at a rate of $50 \mathrm{~mL} / \mathrm{min}$ onto an aluminum starch table $(4.48 \mathrm{~cm} \times 2.44 \mathrm{~m})$ set at a $0.6^{\circ}$ pitch. The overflow containing the gluten and other impurities was collected at the distal end of the starch table. After pumping of the millstarch slurry was completed, the decant water was pumped onto the table at a rate of 50 $\mathrm{mL} / \mathrm{min}$ to rinse the starch fraction. The starch then settled on the table and was rinsed with water to remove any protein particles remaining on the surface of the starch. The collected gluten fraction was dried in a forced-air oven. The starch was dried on the table overnight. On the following day, the partially dried starch was scraped from the table and dried in a forced-air oven to determine the starch dry weight.

The laboratory wet-milling procedures used by three collaborating laboratories involved differences in sample size, volumes of collected slurries, operating steps, material flow, and equipment, consequently influencing the milling quantity and quality of maize. In the steeping step, all laboratories used similar concentrations of $\mathrm{SO}_{2}$ and lactic acid concentration and similar temperature of steeping solution, but longer steeping time was used in Laboratory 2. All laboratory procedures applied a Warning type blender for the first grind of the steeped maize, but the degermed slurry was ground with a plate mill (Laboratory 1) or a blender (Laboratory 2 and Laboratory 3). In the procedures used by Laboratory 1 and Laboratory 3, the fiber fraction separated into coarse and fine fiber was recovered via extensive washing and screening on the 7-, 50-, and 200-mesh sieves, whereas Laboratory 2 collected bran fraction with the 40- and 230-mesh sieves after the second grind. All laboratories used aluminum starch tables for starch-gluten separation, but the procedures differed in millstarch flow rate and the table size and pitch.

Statistical Analysis. Duplicate data of a maize hybrid within each laboratory were averaged. This average value representing the laboratory was subsequently assigned to a specific rank according to the Youden ranking test (19). With each test, all ranking scores of an individual laboratory were summed. The sum of a laboratory was examined by the allowable limits for ranking scores to determine the laboratories with extreme scores.

Apart from the Youden ranking test, Cochran repeatability and Grubb reproducibility tests were applied to the raw data to determine outliers. Cochran's repeatability test was applied to the raw data to detect laboratories with extreme individual values among a set of replicate data. Laboratories with extreme mean values were also identified by applying single and pair Grubbs reproducibility tests. Outliers from Cochran and Grubb tests were compared to those from the Youden ranking tests.

Analysis of variance of a corroborative study data was performed on each test as described in Youden and Steiner (19) to determine repeatability $\left(s_{\mathrm{r}^{\prime}}\right.$ pooled standard deviation within laboratories), reproducibility $\left(s_{\mathrm{R}^{\prime}}\right.$ pooled standard deviation within and between laboratories), repeatability relative standard deviation $\left(\mathrm{RSD}_{\mathrm{r}^{\prime}}\right.$ coefficient of variation within laboratories), and reproducibility relative standard deviation $\left(\mathrm{RSD}_{\mathrm{R}^{\prime}}\right.$ coefficient of variation within and between laboratories).

The mean difference of dry- and wet-milled product yields among hybrids, laboratories, and clusters was determined using least significant differences (LSD) at $\alpha=0.05$. All statistical analyses were conducted using SAS software (27).

\section{Results and Discussion}

Comparison of Compositional and Physical properties. Means of compositional and physical properties averaged over six collaborating laboratories are presented in Table 1 . Most of these properties appeared to differ significantly among maize hybrids, as demonstrated in previous studies $(2,3,6,7,9,28-32)$. With the hybrid effect on maize quality, changes in maize quality properties are highly influenced by environmental effects and growing and postharvesting conditions. This includes plant location (6), whose effect was observed in two hybrids (Garst 8454 and Trisler T-5244) in this study, drying air temperature $(30,33)$, growing season (2), cultural practice (7), and insect and fungus damage (34). Means and range values for compositional and physical properties also varied from laboratory to laboratory (Table 2). For example, Laboratory 6 showed a wider range of test weights (65.6$80.7 \mathrm{~kg} / \mathrm{hl}$ ) than other laboratories. In spite of the use of the same maize hybrids for the evaluation of maize quality properties, significantly different values among laboratories regardless of the properties indicate the presence of non-negligible variation between laboratories. The quality properties tested in the present study have been long understood as easily measurable and important factors to predict and describe the end-use quality $(1,3-5,31)$; however, as observed in this corroborative study, all methods are unlikely to give consistent results for every laboratory and to be practical for the use in the grain industry (6).

Partial correlation coefficients among compositional and physical properties averaged across laboratories are given in Table 3. Generally, the correlation coefficients among the properties were not high and insignificant, which may be attributed to the diversity of maize hybrids and disagreement of determinations on the same sample between laboratories. In addition to the variation due to hybrid and laboratory difference, factors such as kernel size and shape, moisture, and heat treatment, which should be carefully considered prior to the evaluation and the interpretation of these properties $(3,31)$, might have influenced the results to some extent. 


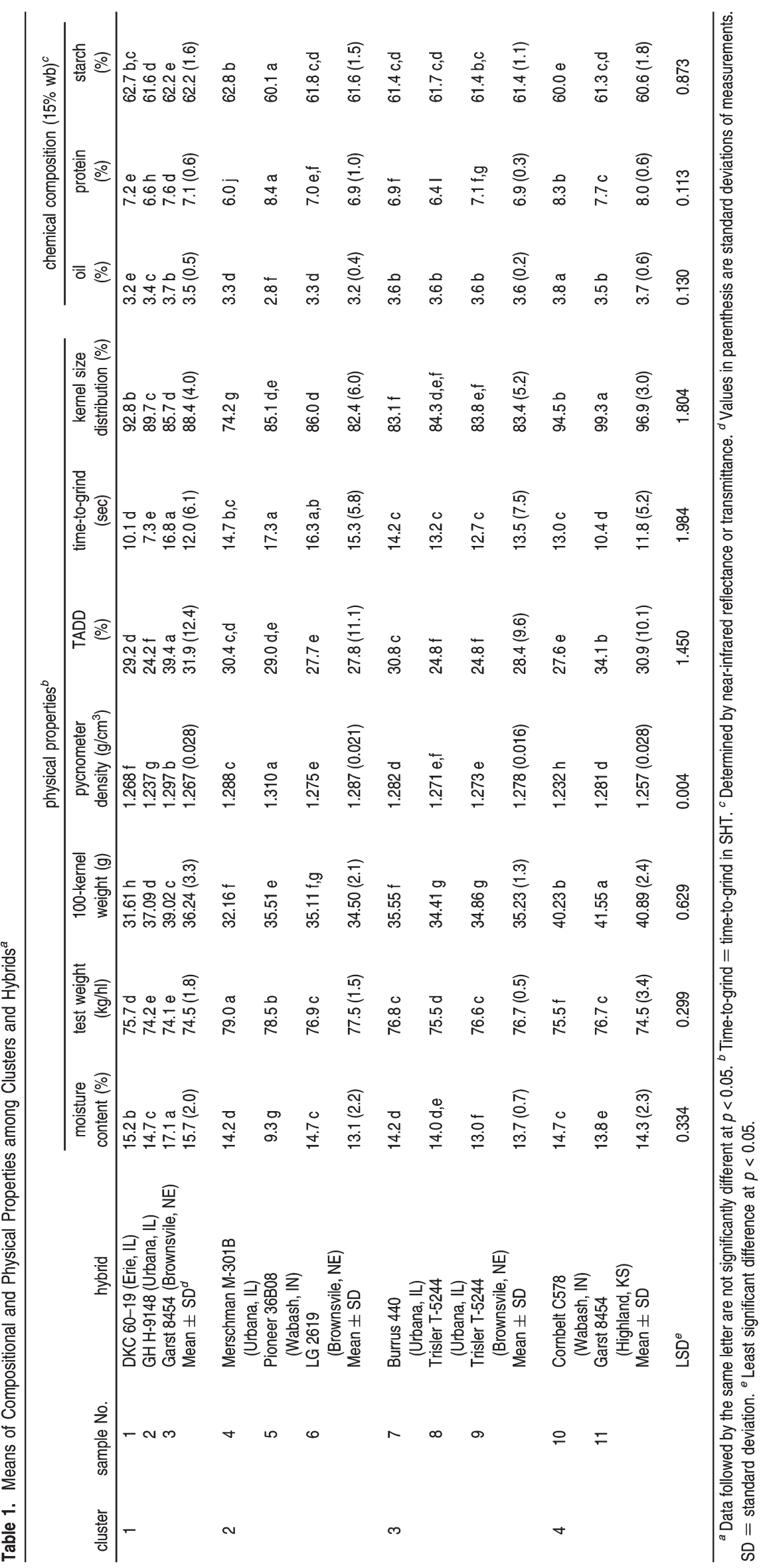


Table 2. Means and Ranges of Compositional and Physical Properties among Collaborating Laboratories ${ }^{a}$

\begin{tabular}{|c|c|c|c|c|c|c|c|c|c|c|c|c|}
\hline \multirow{2}{*}{$\begin{array}{l}\text { compositional and } \\
\text { physical properties }\end{array}$} & \multicolumn{2}{|c|}{ laboratory 1} & \multicolumn{2}{|c|}{ laboratory 2} & \multicolumn{2}{|c|}{ laboratory 3} & \multicolumn{2}{|c|}{ laboratory 4} & \multicolumn{2}{|c|}{ laboratory 5} & \multicolumn{2}{|c|}{ laboratory 6} \\
\hline & mean & range & mean & range & mean & range & mean & range & mean & range & mean & range \\
\hline $\begin{array}{l}\text { moisture } \\
\text { content (\%) }\end{array}$ & 14.4 & $9.4-19.0$ & 14.0 & $10.8-18.3$ & 14.4 & $8.6-18.2$ & 13.4 & $9.2-15.4$ & 13.3 & $8.1-17.2$ & 14.7 & $12.2-19.0$ \\
\hline $\begin{array}{l}\text { test weight } \\
(\mathrm{kg} / \mathrm{hl})\end{array}$ & 76.1 & $71.7-78.9$ & 76.4 & $72.3-79.9$ & 76.2 & $73.0-78.4$ & 76.2 & $70.7-79.7$ & 76.0 & $73.2-79.0$ & 75.8 & $65.6-80.7$ \\
\hline $\begin{array}{l}\text { 100-kernel } \\
\text { weight }(\mathrm{g})\end{array}$ & 37.1 & $32.2-42.0$ & 35.9 & $30.6-42.4$ & 34.5 & $30.6-40.2$ & 36.3 & $30.8-42.4$ & 37.5 & $31.0-42.2$ & 36.6 & $30.8-45.3$ \\
\hline $\begin{array}{l}\text { pycnometer } \\
\text { density }\left(\mathrm{g} / \mathrm{cm}^{3}\right)\end{array}$ & 1.276 & $1.222-1.322$ & 1.281 & $1.243-1.305$ & 1.271 & $1.233-1.314$ & 1.289 & $1.225-1.340$ & 1.270 & $1.227-1.311$ & 1.254 & $1.206-1.302$ \\
\hline TADD (\%) & 42.8 & $34.9-51.3$ & & & 29.2 & $21.5-40.0$ & & & & & 19.6 & $13.3-27.5$ \\
\hline $\begin{array}{l}\text { time-to-grind } \\
(\mathrm{sec})\end{array}$ & & & & & 21.5 & $17.4-25.9$ & & & 11.9 & $9.3-19.7$ & 7.9 & $5.0-13.0$ \\
\hline $\begin{array}{l}\text { kernel size } \\
\text { distribution }(\%)^{c}\end{array}$ & & & & & 96.9 & $94.7-98.7$ & 88.9 & $76.1-98.5$ & 82.8 & $67.7-99.8$ & 88.4 & $75.0-99.9$ \\
\hline oil $(\%)$ & 3.4 & $2.5-4.2$ & 3.6 & $3.2-4.0$ & 3.8 & $3.0-5.3$ & 3.3 & $2.4-3.8$ & 3.1 & $2.6-4.0$ & & \\
\hline protein $(\%)$ & 6.8 & $5.8-8.0$ & 7.5 & $6.4-9.0$ & 7.2 & $5.9-9.1$ & 7.1 & $6.1-8.5$ & 7.0 & $5.5-8.8$ & & \\
\hline starch (\%) & 61.9 & $56.9-65.5$ & 61.4 & $60.2-62.5$ & 59.7 & $56.1-61.9$ & 62.2 & $60.5-63.6$ & 62.3 & $59.8-64.1$ & & \\
\hline
\end{tabular}

${ }^{a}$ Some properties were not determined on maize samples because of a lack of instruments or experiences of collaborating laboratories. ${ }^{b}$ Time-to-grind $=$ time-to-grind in SHT. Oil, protein, and starch contents are based on $15 \%$ moisture content (wb). ${ }^{~}$ Laboratory 3 used a $6.75 \mathrm{~mm}\left(17 / 64^{\prime \prime}\right)$ round hole screen instead of $7.97 \mathrm{~mm}\left(20 / 644^{\prime \prime}\right)$ in the suggested operating procedure.

Table 3. Partial Correlation Coefficients between Compositional and Physical Properties Averaged Across Laboratories at Constant Moisture Content ${ }^{a}$

\begin{tabular}{|c|c|c|c|c|c|c|c|c|}
\hline & $\begin{array}{c}\text { 100-kernel } \\
\text { weight }\end{array}$ & $\begin{array}{l}\text { pycnometer } \\
\text { density }\end{array}$ & TADD & time-to-grind $b$ & $\begin{array}{l}\text { kernel size } \\
\text { distribution }\end{array}$ & oil & protein & starch \\
\hline $\begin{array}{l}\text { test weight } \\
\text { 100-kernel weight } \\
\text { pycnometer density } \\
\text { TADD } \\
\text { time-to-grind } \\
\text { kernel size } \\
\quad \text { distribution } \\
\text { oil } \\
\text { protein }\end{array}$ & $\begin{array}{l}-0.503^{d} \\
(110)\end{array}$ & $\begin{array}{l}\mathbf{0 . 5 2 0 ^ { d }} \\
(113) \\
-0.168 \\
(115)\end{array}$ & $\begin{array}{l}0.206 \\
(44) \\
0.265 \\
(46) \\
0.613^{d} \\
(49)\end{array}$ & $\begin{array}{l}0.078 \\
(53) \\
-0.312^{c} \\
(53) \\
0.490^{d} \\
(56) \\
0.706^{d} \\
(32)\end{array}$ & $\begin{array}{l}-0.511^{d} \\
(60) \\
0.604^{d} \\
(60) \\
-0.246 \\
(60) \\
0.283 \\
(19) \\
-0.307 \\
(37)\end{array}$ & $\begin{array}{l}-0.221^{c} \\
(94) \\
0.101 \\
(95) \\
-0.313^{d} \\
(98) \\
-0.693^{d} \\
(29) \\
0.549^{d} \\
(38) \\
0.316 \\
\\
(41)\end{array}$ & $\begin{array}{l}-0.378^{d} \\
(94) \\
0.535^{d} \\
(95) \\
-0.035 \\
(98) \\
-0.147 \\
(29) \\
0.239 \\
(38) \\
0.648^{d} \\
(41) \\
0.234^{c}(98)\end{array}$ & $\begin{array}{l}0.293 \\
(92) \\
-0.141 \\
(94) \\
0.189 \\
(96) \\
0.766^{d} \\
(27) \\
-0.706^{d} \\
(36) \\
-0.665^{d} \\
(41) \\
-0.629^{d}(96) \\
-0.486^{d}(96)\end{array}$ \\
\hline
\end{tabular}

\footnotetext{
${ }^{a}$ Values in parenthesis are numbers of measurements. Correlation coefficients greater than $|\boldsymbol{l}|=0.45$ are bold-printed. ${ }^{b}$ time-to-grind $=$ time-to-grind in Stenvert
} Hardness Tester. ${ }^{c}$ significance at $p<0.05 ;{ }^{d}$ significance at $p<0.01$.

Correlations between compositional and physical properties for an individual laboratory show how laboratories testing identical samples can substantially differ from each other (Table 4). As would be expected, correlation coefficients among the properties within an individual laboratory were higher than those averaged across laboratories and less often vice versa, indicating that unsatisfactory correlation coefficients of the averaged values might be ascribed to deviant values from one or two of the collaborating laboratories and large variation between laboratories.

Repeatability and Reproducibility of Compositional and Physical Properties. The sources of errors were studied using procedures described in Youden and Steiner (19) (Table 5). Results were treated with Cochran repeatability and Grubb reproducibility tests to identify outliers. No outliers were identified for pycnometer density, kernel size distribution, and oil content using these techniques; however, the Cochran repeatability test did identify GH H-9148 (in moisture and starch content) and DKC 60-19 (in test weight) from Laboratory 1, GH H-9148 (in TADD and time-to-grind), Garst 8454_NE (in moisture, test weight, and protein content), Merschman M-
301B (in TADD), LG 2619 (in 100-kernel weight), Cornbelt C578 (in test weight), and Garst 8454_KS (in starch content) from Laboratory 3, and Pioneer 36B08 (in moisture content) and LG 2619 (in time-to-grind) from Laboratory 6. The only outliers identified by Grubb reproducibility tests were two hybrids evaluated in Laboratory 3: Merschman M-301B (in starch content) and Garst 8454_KS (in 100-kernel weight and starch content). These results indicate that Laboratory 3 operated with less precision or experience, and, to a lesser extent, a similar observation could be extended to Laboratories 1 and 6 .

A two-factor analysis of variance on pooled data (Table 6) as described in Youden and Steiner (19) showed significant differences among hybrids and laboratories and significant laboratory $\times$ hybrid interaction for all compositional and physical properties. The significance of the hybrid effect for the properties was stronger than that of the laboratory effect except for TADD, time-to-grind, oil content, and starch content. In TADD and time-to-grind properties, for which only three laboratories participated, however, the variation for the laboratory component was much larger than that for the hybrid component. The modest and low reproducibility, as measured by the F-values 
Table 4. Partial Correlation Coefficients between Compositional and Physical Properties within an Individual Laboratory at Constant Moisture Content ${ }^{2}$

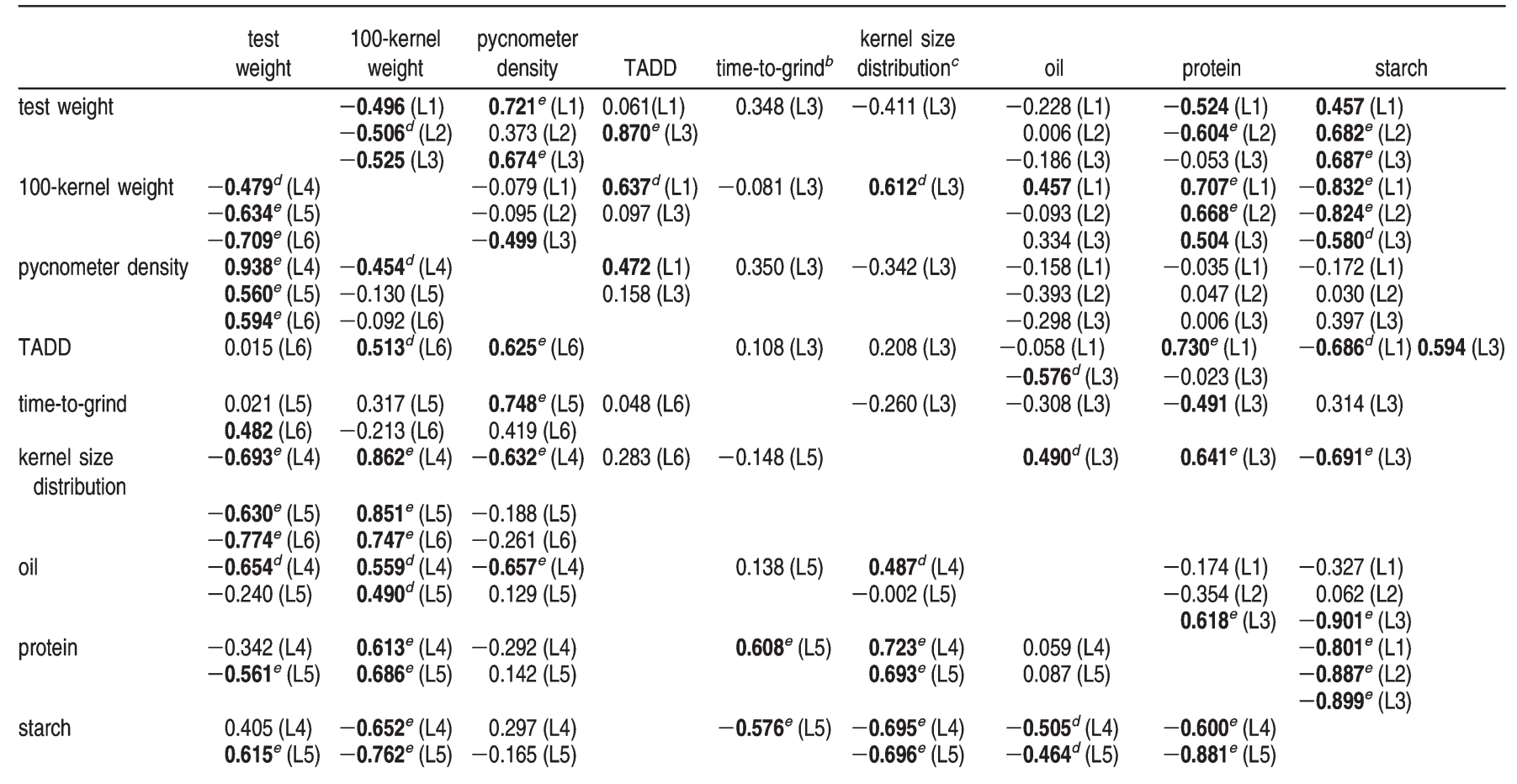

${ }^{a}$ The 'L' in parenthesis represents an individual laboratory (e.g., $\mathrm{L} 1=$ Laboratory 1). Correlation coefficients greater than $|r|=0.45$ are bold-printed. The top right triangle contains correlation coefficients for Laboratories 1, 2, and 3 while the lower left triangle for Laboratories 4,5 , and $6 .{ }^{b}$ Time-to-grind $=$ time-to-grind in Stenvert Hardness Tester. ${ }^{c}$ The results of Laboratory 3 for kernel size distribution were used only for partial correlation coefficients between the quality properties within the laboratory, but not those averaged across laboratories. ${ }^{d}$ Significance at $p<0.05 ;{ }^{e}$ Significance at $p<0.01$.

Table 5. Repeatability and Reproducibility of Compositional and Physical Properties

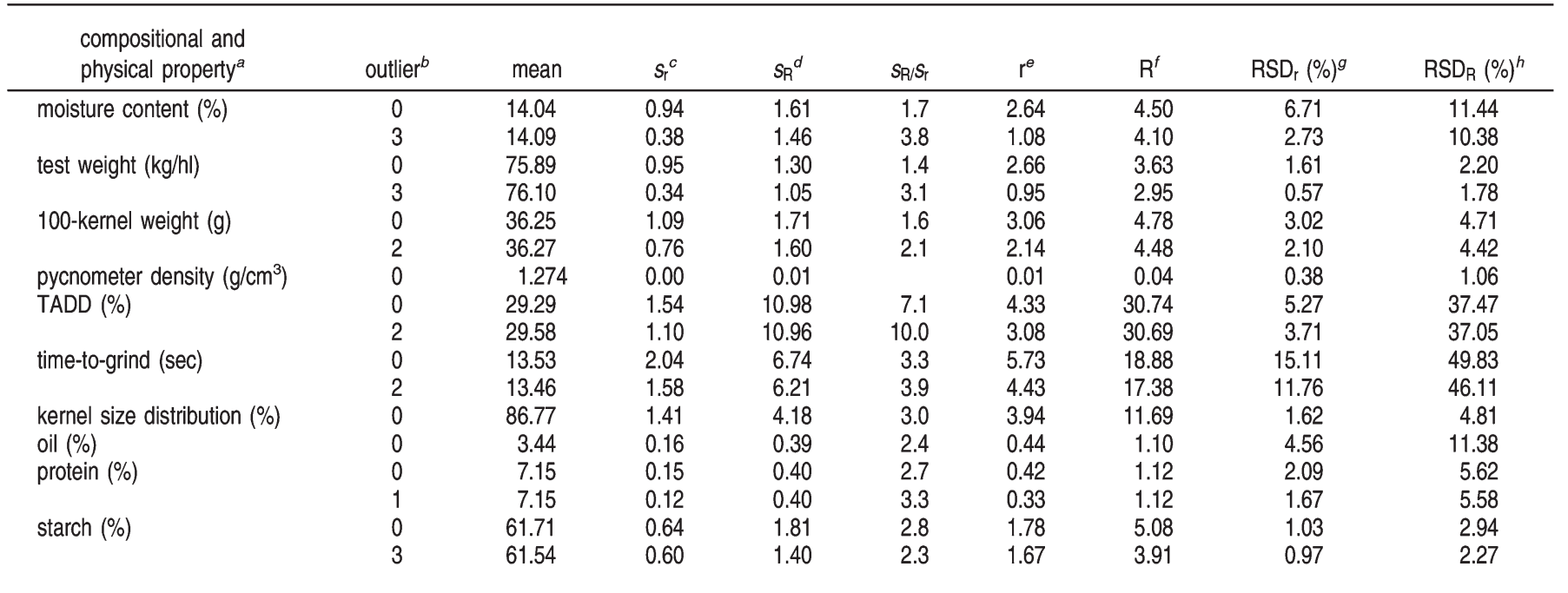

${ }^{a}$ Time-to-grind $=$ time-to-grind in SHT. Oil, protein, and starch contents determined by near-infrared reflectance or transmittance are based on $15 \%$ moisture content (wb). ${ }^{b}$ Number of outliers removed by Cochran repeatability (1-tail, $p=0.01$ ) and Grubb reproducibility (1-tail, $p=0.01$ ) tests. ${ }^{c}$ Repeatability standard deviation (pooled standard deviation within laboratories). ${ }^{d}$ Reproducibility standard deviation (pooled standard deviation within and between laboratories). ${ }^{e}$ Repeatability value $\left(2.8 \times S_{R}\right)$. ${ }^{f}$ Reproducibility value $\left(2.8 \times S_{R}\right) \cdot{ }^{g}$ Repeatability relative standard deviation (coefficient of variation within laboratories). ${ }^{h}$ Reproducibility relative standard deviation (coefficient of variation within and between laboratories).

for the laboratory effect, may partially explain the differences in the results of the maize quality properties and millability among scientific literatures cited in the present study.

The analysis of variance (ANOVA) results were used to determine the repeatability and reproducibility of each property with and without outliers removed. The repeatability precision values for compositional and physical properties in Table 5 were mostly acceptable, indicating good agreement of replicates on the same hybrid in the same laboratory. After discard- ing outliers, RSD ranged from 0.38 to $4.56 \%$, and $\mathrm{RSD}_{\mathrm{R}}$ ranged from 1.06 to 11.38 , except for TADD and time-to-grind. The reproducibility precision values are typically greater than the repeatability precision values (19). In this corroborative study, the ratios of reproducibility to repeatability precision values were greater than 3 in most properties after removing outliers, which reflects the differences among laboratories. The laboratory variation is likely attributable to differences in operator, instrumentation, and laboratory environment. A slightly 
Table 6. Analysis of Variance for the Effects of Collaborating Laboratories and Maize Hybrids on Compositional and Physical Properties

\begin{tabular}{|c|c|c|c|}
\hline $\begin{array}{l}\text { compositional and } \\
\text { physical property }\end{array}$ & $F$-value & $p$-value & $r^{2}$ \\
\hline $\begin{array}{l}\text { moisture content } \\
\text { laboratory }(L) \\
\text { hybrid }(H) \\
L \times H\end{array}$ & $\begin{array}{r}25.70 \\
242.58 \\
28.17\end{array}$ & $\begin{array}{l}<0.0001 \\
<0.0001 \\
<0.0001\end{array}$ & 0.985 \\
\hline $\begin{array}{l}\text { test weight } \\
\text { laboratory }(L) \\
\text { hybrid }(H) \\
L \times H\end{array}$ & $\begin{array}{r}10.54 \\
235.95 \\
18.97\end{array}$ & $\begin{array}{l}<0.0001 \\
<0.0001 \\
<0.0001\end{array}$ & 0.983 \\
\hline $\begin{array}{l}\text { 100-kernel weight } \\
\text { laboratory }(L) \\
\text { hybrid }(H) \\
L \times H\end{array}$ & $\begin{array}{r}42.86 \\
204.92 \\
4.31\end{array}$ & $\begin{array}{l}<0.0001 \\
<0.0001 \\
<0.0001\end{array}$ & 0.974 \\
\hline $\begin{array}{l}\text { pycnometer density } \\
\text { laboratory }(L) \\
\text { hybrid }(H) \\
L \times H\end{array}$ & $\begin{array}{r}117.17 \\
313.48 \\
4.78\end{array}$ & $\begin{array}{l}<0.0001 \\
<0.0001 \\
<0.0001\end{array}$ & 0.983 \\
\hline $\begin{array}{l}\text { TADD } \\
\text { laboratory }(L) \\
\text { hybrid }(H) \\
L \times H\end{array}$ & $\begin{array}{r}2082.01 \\
82.15 \\
9.69\end{array}$ & $\begin{array}{l}<0.0001 \\
<0.0001 \\
<0.0001\end{array}$ & 0.995 \\
\hline $\begin{array}{l}\text { time-to-grind }^{a} \\
\text { laboratory }(\mathrm{L}) \\
\text { hybrid }(H) \\
L \times H\end{array}$ & $\begin{array}{r}298.12 \\
8.78 \\
2.94\end{array}$ & $\begin{array}{r}<0.0001 \\
<0.0001 \\
0.0048\end{array}$ & 0.968 \\
\hline $\begin{array}{l}\text { kernel size distribution } \\
\text { laboratory }(L) \\
\text { hybrid }(H) \\
L \times H\end{array}$ & $\begin{array}{r}208.14 \\
254.24 \\
13.43\end{array}$ & $\begin{array}{l}<0.0001 \\
<0.0001 \\
<0.0001\end{array}$ & 0.982 \\
\hline $\begin{array}{l}\text { oil }^{b} \\
\text { laboratory }(L) \\
\text { hybrid }(H) \\
L \times H\end{array}$ & $\begin{array}{r}57.82 \\
31.05 \\
6.81\end{array}$ & $\begin{array}{l}<0.0001 \\
<0.0001 \\
<0.0001\end{array}$ & 0.943 \\
\hline $\begin{array}{l}\text { protein }^{b} \\
\text { laboratory }(L) \\
\text { hybrid }(H) \\
L \times H\end{array}$ & $\begin{array}{r}99.37 \\
392.80 \\
13.49\end{array}$ & $\begin{array}{l}<0.0001 \\
<0.0001 \\
<0.0001\end{array}$ & 0.990 \\
\hline $\begin{array}{l}\operatorname{starch}^{b} \\
\text { laboratory (L) } \\
\text { hybrid }(H) \\
L \times H\end{array}$ & $\begin{array}{r}57.70 \\
18.88 \\
5.13\end{array}$ & $\begin{array}{l}<0.0001 \\
<0.0001 \\
<0.0001\end{array}$ & 0.928 \\
\hline
\end{tabular}

\footnotetext{
${ }^{a}$ time-to-grind $=$ time-to-grind in SHT. ${ }^{b}$ Oil, protein, and starch contents determined by near-infrared reflectance or transmittance are based on $15 \%$ moisture content (wb).
}

higher repeatability and reproducibility standard deviation values of proximate content determined by NIR or NIT in this study compared with those reported in previous works are thought to be due to the use of the different calibration and the instrument models (35). The acceptably low repeatability and reproducibility standard deviation values obtained from this study are likely to ensure that operating procedures currently used in grain quality laboratories are mostly reliable and consistent enough for use as a routine test.

According to the Youden ranking test (19), in which a laboratory with the largest result is assigned as rank 1 and the same result between laboratories for $x$ th rank is given the rank $x \pm 0.5$ for each laboratory, all laboratories were within the allowable score limits only in test weight and starch content (Table 7); however, despite a relatively simple procedure of 100-kernel weight, Laboratory 3, with consistently low results, and Laboratory 5, with consistently high results, were detected as outliers among laboratories, suggesting review of their procedures, techniques, and instrumentation is necessary, as compared to those of other collaborating laboratories. For a pycnometer density test, Laboratories 4 and 6 presented rather consistent positions relative to other laboratories. As anticipated, the results for TADD and time-to-grind were not satisfactory in this ranking test. The results from the Youden ranking tests indicate that laboratories with consistently extreme results should carefully search for the source of systemic error and review the interpretation of the results from the same procedure and equipment used in this study and, if necessary, revise the test procedures.

Evaluation of Compositional and Physical Properties. The moisture content determined on the same sample was significantly different among laboratories in the present study (Tables 5 and 7). As a result, the determinations of physical properties were reported on an 'as is' basis without moisture adjustment. The accurate determination of moisture content is important in terms of economic, quality, and analytical aspects $(36,37)$. Most grain quality properties (kernel weight and volume, density, stress crack, and breakage susceptibility) and chemical compositions are affected by moisture content $(1,6,31,38-41)$.

Test weight has been an important and useful quality property in determining maize grades and selling price $(1,40)$, although it is a poor indicator of maize quality for processing and milled products $(6,31,42)$. All maize hybrids used in the present study had test weights greater than U.S. Grade No. 2 (69.50 kg/hl) (43). Improved accuracy in determining test weight needs to consider many factors, such as void volume, packing, kernel size and shape, moisture content, mechanical and heat treatment, percentage of broken kernel and foreign materials, variety difference, contamination of microorganism, and kernel hardness $(5,9,16,28,34,38,40,44-46)$. In the present study, the hybrid effect on test weight was more significant than the laboratory effect (Table 6), suggesting a relatively good agreement between laboratories because of its simplicity and log use as an indicator of maize quality. Test weight (bulk density) was significantly correlated with pycnometer density (kernel density) $(r=0.520, p<0.01)$ (Table 3), which is consistent with previous works $(14,40)$.

Pycnometer density is an indirect measurement of the percentage of vitreous endosperm (9) and maize hardness (3). In the present study, pycnometer density was significantly and positively correlated with TADD $(r=0.613, p<0.01)$ and timeto-grind $(r=0.490, p<0.01)$ (Table 3$)$. Pycnometer density increases with maturity because of the accumulation of the dry matter (8) and decreases with increasing plant density (7) and drying temperature (9). Pycnometer density decreased with increased moisture content $(r=-0.328, p<0.01)$. This has been attributed to the decreased ratio of weight loss to volume increase with increased moisture content (31). Pycnometer density was a more reproducible property than other quality properties as has been mentioned in previous studies $(10,47)$. This was supported by our result that pycnometer density had the lowest relative standard deviations for repeatability and reproducibility among the other property determinations (Table 5).

One-hundred kernel weight was negatively correlated with test weight and pycnometer density, but positively correlated with kernel size distribution (Tables 3 and 4). This indicated that 100-kernel weight is affected to some extent by both the sizes and densities of the kernels $(2,44)$. Kernel size is a factor that has been related to maize quality properties, such as test weight, chemical composition, maize hardness, and the germendosperm ratio, which are associated with endosperm texture and milled product yields $(6,48)$.

Time-to-grind in SHT was significantly correlated with pycnometer density $(r=0.490, p<0.01)$ and TADD $(r=0.706, p<$ 0.01 ) (Table 3); however, significance between such measurements was rarely found within a laboratory (Table 4). This result is likely explained by the highest relative standard devia- 
Table 7. Youden Ranking Scores Obtained by Laboratories for Compositional and Physical Properties ${ }^{a}$

\begin{tabular}{|c|c|c|c|c|c|c|c|c|c|c|}
\hline laboratory & $\begin{array}{c}\text { moisture } \\
\text { content (\%) }\end{array}$ & $\begin{array}{l}\text { test weight } \\
(\mathrm{kg} / \mathrm{hl})\end{array}$ & $\begin{array}{l}\text { 100-kernel } \\
\text { weight }(\mathrm{g})\end{array}$ & $\begin{array}{c}\text { pycnometer } \\
\text { density }\left(\mathrm{g} / \mathrm{cm}^{3}\right)\end{array}$ & $\begin{array}{c}\text { TADD } \\
(\%)\end{array}$ & $\begin{array}{l}\text { time-to-grind } \\
(\sec )^{b}\end{array}$ & $\begin{array}{c}\text { kernel size } \\
\text { distribution (\%) }\end{array}$ & $\begin{array}{l}\text { oil } \\
(\%)^{c}\end{array}$ & $\begin{array}{c}\text { protein } \\
(\%)^{c}\end{array}$ & $\begin{array}{l}\text { starch } \\
(\%)^{c}\end{array}$ \\
\hline 1 & 28.0 & 28.5 & 19.0 & 30.0 & 9.0 & & & 30.0 & 38.0 & 29.0 \\
\hline 2 & 50.0 & 22.5 & 31.0 & 22.0 & & & & 15.0 & 12.0 & 35.0 \\
\hline 3 & 25.0 & 44.0 & 51.0 & 34.0 & 18.0 & 10.0 & & 15.0 & 25.0 & 33.0 \\
\hline 4 & 34.0 & 35.0 & 39.0 & 12.0 & & & 14.0 & 34.0 & 28.0 & 21.0 \\
\hline 5 & 36.0 & 33.0 & 17.0 & 40.0 & & 21.0 & 28.0 & 41.0 & 32.0 & 17.0 \\
\hline 6 & 46.0 & 26.0 & 32.0 & 51.0 & 27.0 & 29.0 & 26.0 & & & \\
\hline
\end{tabular}

${ }^{a}$ Extreme results are bold-printed. According to the Youden ranking test (19), the allowable limits are 18-45 (for moisture content, test weight, 100-kernel weight, and pycnometer density), 12-24 (for TADD), 13-27 (for time-to-grind and kernel size distribution), and 16-38 (for oil, protein, and starch content), respectively. ${ }^{b}$ time-to-grind $=$ time-to-grind in SHT. ${ }^{\circ}$ Oil, protein, and starch contents determined by near-infrared reflectance or transmittance are based on $15 \%$ moisture content (wb).

Table 8. Means of Dry-milled Product Yields in Two Collaborating Laboratories ${ }^{a}$

\begin{tabular}{|c|c|c|c|c|c|c|c|c|c|}
\hline \multirow[b]{2}{*}{ hybrid } & \multicolumn{4}{|c|}{ laboratory $1(\%)$} & \multicolumn{5}{|c|}{ laboratory $2(\%)$} \\
\hline & total grits ${ }^{b}$ & germ & pericarp & fines & total grits & meals & cones & flour & feeds \\
\hline GH H-9148_IL & $55.7 \mathrm{~d}$ & $12.1 \mathrm{a}$ & $8.1 \mathrm{a}$ & $23.9 \mathrm{a}$ & $57.6 \mathrm{c}$ & $6.4 \mathrm{a}$ & $5.7 \mathrm{a}$ & $1.7 \mathrm{a}, \mathrm{b}$ & $29.3 \mathrm{a}$ \\
\hline Garst 8454_NE & $66.5 \mathrm{a}$ & $8.9 \mathrm{c}$ & $6.9 \mathrm{~b}, \mathrm{c}$ & $17.3 d$ & $64.5 \mathrm{a}$ & $4.5 \mathrm{C}$ & $4.1 \mathrm{c}$ & $1.3 b$ & $27.8 \mathrm{a}$ \\
\hline Merschman M-301B & $59.1 \mathrm{~b}, \mathrm{c}$ & $10.9 a, b$ & $8.0 a, b$ & $21.4 b$ & $61.4 b$ & $4.7 b, c$ & $4.5 \mathrm{~b}, \mathrm{c}$ & $1.8 a, b$ & $27.7 \mathrm{a}$ \\
\hline Pioneer 36B08 & $65.1 \mathrm{a}$ & $10.5 \mathrm{a}, \mathrm{b}, \mathrm{c}$ & $6.5 \mathrm{c}$ & $16.9 \mathrm{~d}$ & $63.1 a, b$ & $5.1 \mathrm{~b}, \mathrm{c}$ & $4.7 \mathrm{~b}$ & $1.5 a, b$ & $25.5 \mathrm{a}$ \\
\hline LG 2619 & $60.3 b$ & $11.6 a, b$ & $8.1 \mathrm{a}$ & $19.7 \mathrm{C}$ & $61.2 \mathrm{~b}$ & $4.3 \mathrm{C}$ & $4.4 \mathrm{~b}, \mathrm{c}$ & $1.8 a, b$ & $28.3 \mathrm{a}$ \\
\hline Burrus 440 & $60.1 \mathrm{~b}$ & $11.2 a, b$ & $7.9 \mathrm{a}, \mathrm{b}$ & $20.2 b, c$ & $61.1 \mathrm{~b}$ & $5.1 \mathrm{~b}, \mathrm{c}$ & $4.7 \mathrm{~b}, \mathrm{c}$ & $1.8 a, b$ & $27.4 \mathrm{a}$ \\
\hline Trisler T-5244_IL & $56.9 \mathrm{c}, \mathrm{d}$ & $10.9 a, b$ & $8.3 \mathrm{a}$ & $23.8 \mathrm{a}$ & $61.8 a, b$ & $5.1 \mathrm{~b}, \mathrm{c}$ & $4.6 \mathrm{~b}, \mathrm{c}$ & $1.9 \mathrm{a}$ & $26.6 \mathrm{a}$ \\
\hline Trisler T-5244_NE & $61.2 \mathrm{~b}$ & $9.9 b, c$ & $7.7 \mathrm{a}, \mathrm{b}$ & $21.0 \mathrm{~b}, \mathrm{c}$ & $61.6 a, b$ & $4.8 \mathrm{~b}, \mathrm{c}$ & $4.6 \mathrm{~b}, \mathrm{c}$ & $1.7 a, b$ & $27.2 \mathrm{a}$ \\
\hline Cornbelt C578 & $64.4 \mathrm{a}$ & $10.1 \mathrm{~b}, \mathrm{c}$ & $7.8 a, b$ & $17.4 \mathrm{~d}$ & $61.4 \mathrm{~b}$ & $5.4 \mathrm{~b}$ & $4.9 \mathrm{~b}$ & $1.8 a, b$ & $26.5 \mathrm{a}$ \\
\hline mean & 61.0 & 10.7 & 7.7 & 20.1 & 61.5 & 5.1 & 4.7 & 1.6 & 27.8 \\
\hline $\mathrm{SD}^{c}$ & 3.7 & 1.0 & 0.6 & 2.5 & 2.0 & 0.6 & 0.5 & 0.3 & 2.2 \\
\hline $\min$ & 54.7 & 8.6 & 6.5 & 16.6 & 57.1 & 4.2 & 3.8 & 0.8 & 25.3 \\
\hline $\max$ & 66.9 & 12.9 & 8.6 & 24.7 & 67.1 & 6.7 & 5.9 & 2.0 & 34.0 \\
\hline $\mathrm{LSD}^{d}$ & 2.364 & 1.887 & 1.033 & 1.590 & 3.131 & 0.881 & 0.596 & 0.556 & 3.95 \\
\hline
\end{tabular}

${ }^{a}$ Data followed by the same letter are not significantly different at $p<0.05$. The same laboratory number among maize quality, dry-and wet-milling properties does not mean the same laboratory. ${ }^{b}$ Total grits yield was computed as a sum of all grits yields obtained during dry-milling. ${ }^{c}$ Standard deviation. ${ }^{d}$ Least significant difference at $p<0.05$.

Table 9. Correlation Coefficients between Dry-milled Product Yields within Each Collaborating Laboratory ${ }^{a}$

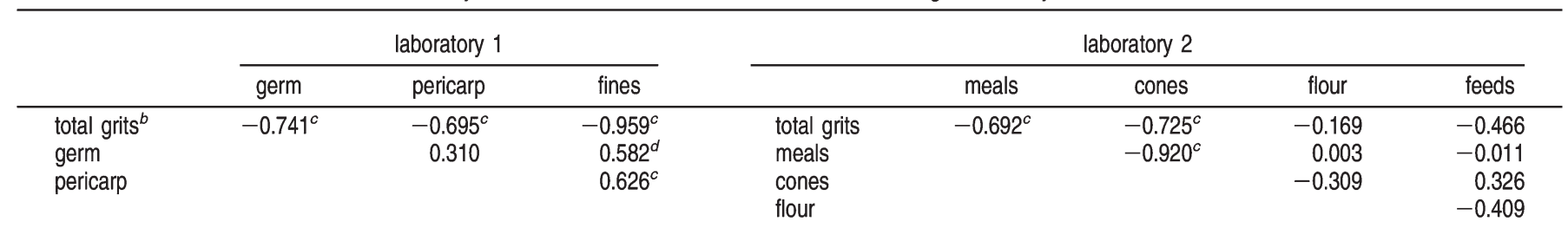

${ }^{a}$ Correlation coefficients greater than $I n=0.45$ are bold-printed. ${ }^{b}$ Total grits yield was computed as a sum of all grits yields obtained during dry-milling. ${ }^{c}$ Significance at $p<0.01 .{ }^{d}$ Significance at $p<0.05$.

Table 10. Correlation Coefficients between Compositional and Physical Properties and Dry-milled Product Yields ${ }^{a}$

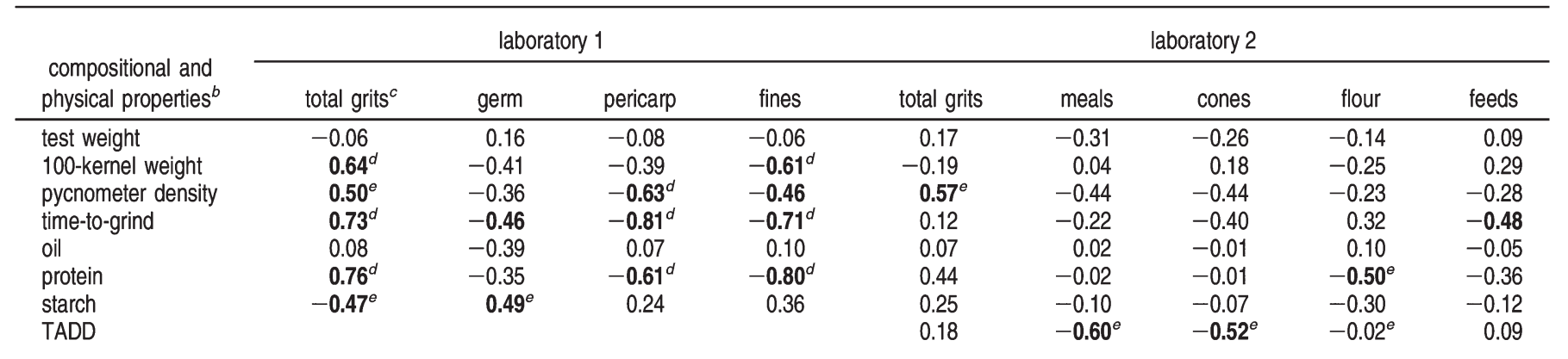

\footnotetext{
${ }^{a}$ Correlation coefficients greater than $I n=0.45$ are bold-printed. ${ }^{b}$ Tme-to-grind $=$ time-to-grind in SHT. ${ }^{c}$ Total grits yield was computed as a sum of all grits yields obtained during dry-milling. ${ }^{d}$ Significance at $p<0.01$. ${ }^{e}$ Significance at $p<0.05$.

tions for repeatability and reproducibility for time-to-grind among maize quality tests. SHT is an appropriate instrument to determine maize hardness $(4,41)$. Flinty maizes typically have longer grinding time and higher ratios of coarse-to-fine particles
} 
and Fox et al. (49) suspected the reliability of SHT grinding time due to clogging of the collected particles.

TADD has been used to assess kernel hardness on a variety of grains, including maize, sorghum, and wheat $(6,17,22,50$, 51). TADD was highly and significantly correlated with other compositional and physical properties averaged across laboratories (Table 3), including pycnometer density $(r=0.613, p<$ $0.01)$, time-to-grind $(r=0.706, p<0.01)$, oil content $(r=-0.693$, $p<0.01)$, and starch content $(r=0.766, p<0.01)$; however, the signs and magnitudes of the correlations varied with laboratories (Table 4). These results were related to the low standard deviation for repeatability and high standard deviation for reproducibility for TADD (Table 5).

Differences in maize proximate compositions were significant among hybrids and laboratories (Table 6). The correlations of chemical compositions with other physical properties varied with laboratories (Tables 3 and 4). Oil content was positively correlated with kernel size distribution, which confirms the findings of Pomeranz et al. (41) and Shandera et al. (6). Protein content was not significantly correlated with hardnessassociated properties, such as TADD, time-to-grind, and pycnometer density; however, positive correlations among them were reported in Manoharkumar et al. (29) and Shandera et al. (6). As expected, the negative correlations between starch content and protein content averaged over laboratories and within an individual laboratory were found. According to the Youden ranking test, three outliers were detected in oil content, one outlier in protein content, and none in starch content. Similar ranking scores observed between laboratories may be in part ascribed to the use of the common calibration.

Dry-milling. Two laboratories using different dry-milling procedures participated in the present study. Therefore, no direct comparison of product yields could be made between laboratories or with previous studies $(10,14,15,29,30,53)$. However, statistical differences in dry-milled products among hybrids were found in both laboratories (Table 8). The procedure used by Laboratory 1 was more sensitive to hybrid difference in differentiating dry-milled products than that by Laboratory 2, in which no significant difference in feeds yields was found among hybrids; however, total grits yield for each hybrid was not significantly different between laboratories except for Trisler T-5244_IL. With correlations between grits yields, the yield of total grits in Laboratory 1 was negatively correlated with germ $(r=-0.741, p<0.01)$, pericarp $(r=-0.695$, $p<0.01)$, and fines yields $(r=-0.959, p<0.01)$ (Table 9). Likewise, Laboratory 2 showed a negative correlation of total grits yield with meals $(r=-0.692, p<0.01)$, cones $(r=-0.725, p<$ $0.01)$, and feeds $(r=-0.466)$. The result of negative correlation between total grits yield and other fractions from both laboratories indicates the fact that the more recovery of endosperm products coincides with the reduction of endosperm included in the other fractions (47). Paulsen and Hill (14) reported that the incomplete separation of germ fraction not only lost oil yield, but also might increase the risk of high oil contamination in a grits fraction. The low oil in grits fractions generally means low ash in those fractions (53).

Dry-milled product yields were significantly correlated with some of compositional and physical properties (Table 10). The correlation coefficients greater than $r=0.45$ were more frequently found in Laboratory 1 than in Laboratory 2. In Laboratory 1 , total grits yield was highly correlated with 100-kernel weight $(r=0.64, p<0.01)$, pycnometer density $(r$ $=0.50, p<0.05)$, time-to-grind $(r=0.73, p<0.01)$, protein $(r=$ $0.76, p<0.01)$, and starch $(r=-0.47, p<0.05)$; however, among the properties, only pycnometer density and protein content were rather highly correlated with total grits yield in Laboratory 2. Protein content appeared to be a better predictor of dry-milled product yields in both laboratories. High grit fraction yields and milling evaluation factor (MEF), known as the best predictor of dry-milling performance, are generally asso- 
Table 12. Correlation Coefficients between Wet-milled Product Yields within Each Collaborating Laboratory ${ }^{a}$

\begin{tabular}{|c|c|c|c|c|c|c|c|c|c|c|c|c|}
\hline & \multicolumn{4}{|c|}{ laboratory 1} & \multicolumn{4}{|c|}{ laboratory 2} & \multicolumn{4}{|c|}{ laboratory 3} \\
\hline & gluten & fiber & germ & steep solids & gluten & bran & germ & steep solids & gluten & fiber & germ & steep solids \\
\hline $\begin{array}{l}\text { starch } \\
\text { gluten } \\
\text { fiber } \\
\text { germ }\end{array}$ & $-0.65^{b}$ & $\begin{array}{c}-0.76^{c} \\
0.28\end{array}$ & $\begin{array}{l}-0.11 \\
-0.17 \\
-0.28\end{array}$ & $\begin{array}{r}-0.04 \\
-0.10 \\
0.09 \\
-0.42\end{array}$ & -0.35 & $\begin{array}{l}-0.02 \\
-0.00\end{array}$ & $\begin{array}{l}-0.080 \\
-0.34 \\
-0.45^{b}\end{array}$ & $\begin{array}{c}-0.35 \\
0.82^{c} \\
-0.39 \\
-0.05\end{array}$ & $-0.94^{c}$ & $\begin{array}{r}-0.36 \\
0.12\end{array}$ & $\begin{array}{c}0.41 \\
-0.55^{c} \\
-0.28\end{array}$ & $\begin{array}{c}-0.54^{b} \\
0.48^{b} \\
0.23 \\
-0.37\end{array}$ \\
\hline
\end{tabular}

${ }^{a}$ Correlation coefficients greater than $|r|=0.45$ are bold-printed. ${ }^{b}$ significance at $p<0.05 .{ }^{c}$ significance at $p<0.01$.

Table 13. Correlation Coefficients between Compositional and Physical Properties and Wet-milled Product Yields ${ }^{a}$

\begin{tabular}{|c|c|c|c|c|c|c|c|c|c|c|c|c|c|c|c|}
\hline \multirow[b]{2}{*}{$\begin{array}{l}\text { compositional and } \\
\text { physical properties }\end{array}$} & \multicolumn{5}{|c|}{ laboratory 1} & \multicolumn{5}{|c|}{ laboratory 2} & \multicolumn{5}{|c|}{ laboratory 3} \\
\hline & starch & gluten & fiber & germ & $\begin{array}{l}\text { steep } \\
\text { solids }\end{array}$ & starch & gluten & bran & germ & $\begin{array}{l}\text { steep } \\
\text { solids }\end{array}$ & starch & gluten & fiber & germ & $\begin{array}{l}\text { steep } \\
\text { solids }\end{array}$ \\
\hline test weight & 0.07 & -0.33 & -0.04 & 0.28 & 0.26 & -0.41 & 0.33 & -0.14 & 0.39 & -0.34 & 0.09 & -0.19 & -0.19 & $0.52^{c}$ & 0.25 \\
\hline 100-kernel weight & $-0.82^{d}$ & $0.72^{d}$ & $0.72^{d}$ & -0.08 & 0.02 & $-0.44^{c}$ & $-0.50^{c}$ & 0.11 & -0.26 & $0.47^{c}$ & -0.41 & 0.41 & 0.31 & -0.41 & 0.21 \\
\hline pycnometer density & -0.03 & -0.01 & 0.05 & -0.42 & $0.91^{d}$ & 0.27 & -0.08 & -0.11 & -0.38 & 0.13 & -0.10 & 0.15 & 0.00 & -0.28 & 0.33 \\
\hline time-to-grind & -0.35 & 0.37 & 0.49 & $-0.75^{c}$ & $0.72^{d}$ & 0.36 & -0.20 & -0.11 & -0.25 & -0.24 & & & & & \\
\hline oil & 0.07 & -0.03 & -0.03 & -0.15 & 0.34 & & & & & & 0.05 & -0.09 & $-0.47^{c}$ & $0.69^{d}$ & -0.07 \\
\hline protein & $-0.74^{d}$ & $0.87^{d}$ & $0.61^{c}$ & -0.30 & -0.05 & & & & & & $-0.75^{d}$ & $0.81^{d}$ & 0.05 & -0.37 & $0.45^{c}$ \\
\hline starch & 0.23 & -0.32 & -0.24 & 0.50 & -0.30 & & & & & & -0.03 & -0.04 & -0.40 & $0.58^{d}$ & 0.33 \\
\hline TADD & & & & & & $-0.72^{d}$ & $-0.49^{c}$ & 0.15 & $-0.52^{c}$ & $0.48^{c}$ & & & & & \\
\hline kernel size distribution & & & & & & 0.01 & -0.08 & 0.17 & -0.21 & 0.10 & & & & & \\
\hline
\end{tabular}

${ }^{a}$ Correlation coefficients greater than $|r|=0.45$ are bold-printed. ${ }^{b}$ Time-to-grind $=$ time-to-grind in SHT. ${ }^{c}$ Significance at $p<0.05 .{ }^{d}$ Significance at $p<0.01$.

ciated with high density, low breakage susceptibility, low broken kernels, low stress crack, and low percentage of floaters (4, $6,14,29,53,54)$. Although such studies reported higher correlations between test weight and dry-milled product yields, the correlations were weaker and their signs often are opposite in the present study. Previous studies $(14,47,55)$ reported that higher kernel protein content was associated with higher density and, thus, the greater quantity of dry-milled grits yields. This concurs with our finding of the higher correlation of protein with a total grits yield in both laboratories. Harder maize has been associated with higher protein content and kernel density and produces higher yields of grits derived from hard endosperm than from softer maize, irrespective of stress cracking $(5,9,52,56,57)$.

Wet-milling. Wet-milled product yields were significantly different among laboratories as well as among hybrids as reported in previous works $(6,31,49,58-60)$. A variation between blind-duplicated samples was relatively small as compared to that caused by hybrid difference within a laboratory. Table 11 also suggested the location (environment) effect for wet-milled product yields of the same hybrid (Garst 8454 and Trisler T-5244) grown at different locations. A hybrid rank for wet-milled product yields was not similar for different laboratories. For example, Cornbelt C578 showed the lowest starch yield in Laboratories 1 and 3 but was ranked second by Laboratory 2 . This implies that a significant difference in the selection of maize hybrids may occur in breeding programs if the final decision was made on the basis of the results from one of the laboratories. Laboratory 1 had lower standard deviations and LSD values than the other two laboratories. Substantially lower standard deviations and LSDs have been reported by Laboratory 3 with different sample sets than those found in the present study. Higher starch yields and lower gluten yields were observed in Laboratory 2 as compared to those in the other laboratories. The difference in starch yield and gluten yield among laboratories may be ascribed to different procedures and equipment settings in starch-protein separation as well as to operator's technique and skill in applying the technique.

The correlation among wet-milled product yields within each collaborating laboratory is presented in Table 12. Starch yield was negatively correlated with gluten yield in all three laboratories. This correlation suggests that an increase of starch content in kernels reduces protein content and, thus, wet-milled gluten yield; however, the correlation between starch yield and gluten yield was not significant in all laboratories. Laboratory 3 had the highest and most significant correlation $(r=-0.94, p<0.01)$ among laboratories. Increased starch yield was coupled with decreased fiber yield, which was more pronounced in Laboratory $1(r=-0.76, p<0.01)$. The reduced starch yield can be partially explained by incomplete fiber separation during washing. Fiber yield has been reported to be positively correlated with the ratio of surface area to mass of kernels $(46,62)$. An inverse relationship was found between germ yield and steep solids, which is believed to generate from germ of the kernels (60). The correlation was weaker in Laboratory 2 than the other two laboratories.

Wet-milled product yields were to some extent associated with compositional and physical properties tested in the present study (Table 13). A modest correlation of maize quality properties with the yield of products from wet-milling found in the present study were mostly consistent with several previous works $(6,26,32,39,42,49)$. Starch yield was significantly correlated with 100-kernel weight $(r=-0.82$ in Laboratory 1 and $r=-0.44$ in Laboratory 2$)$, protein $(r=-0.74$ in Laboratory 1 and $r=-0.75$ in Laboratory 3$)$, and TADD $(r=$ -0.72 in Laboratory 2), but not with kernel starch content. The negative correlation of kernel hardness-associated properties, such as protein content and TADD, with starch yield suggests that starch granules bound with more protein matrices are not easily recovered during wet-milling of harder kernels, which results in high protein content in recovered starch (6, 49). Higher starch yield and lower gluten yield may also be indicative of high protein levels in the starch. Protein determinations need to be made to assess the qualities of starches obtained. Although protein in starch was not measured in the present study, and thus rather weakened the conclusion of reproducibility in starch yield, one could expect its positive correlation with test weight, pycnometer density, kernel protein content, and oil content based on the correlations observed in this study as well as previous studies $(49,62)$. In general, hard kernels and high-temperature drying would be expected to increase protein content in starch $(33,42,59,63)$ whereas 
kernel maturity appeared to be an insignificant factor (46). The grain starch content was not a good indicator of any wetmilled product yields, either. Consistently high correlation of kernel protein content with starch yield throughout laboratories suggests that protein content might be a better determinant for predicting starch yield than kernel starch content. A rather low correlation was found between test weight and starch yield, implying that test weight is not a good indicator of wet-milling quality. This result is in accordance with previous works $(39,42,64)$. As expected, gluten yield was highly correlated with protein content $(r=0.87$ in Laboratory 1 and $r$ $=0.81$ in Laboratory 3$)$ as well as 100-kernel weight $(r=-0.82$ in Laboratory 1 and $r=-0.50$ in Laboratory 2). Measures of 100-kernel weight were positively correlated with fiber yield and negatively with starch yield, which was opposite of the result of Zehr et al. (32). The sign and magnitude of correlation coefficients between 100-kernel weight and gluten yield varied with laboratories. Pycnometer density was significantly correlated with steep solids yield in Laboratory 1. Denser kernels typically negatively impact wet-milling quality and produce more solids in the steeping solution (49). Accordingly, steep solids were positively correlated with grain hardness-associated properties, including time-to-grind $(r=0.72, p<0.01$ in Laboratory 1$)$, TADD ( $r=0.48, p<0.05$ in Laboratory 2$)$, and protein content $(r=0.45, p<0.05$ in Laboratory 3$)$.

There is a need to develop rapid and reliable maize quality properties to adequately predict wet-milling quality and to understand such relationships for the selection of maize hybrids with the best suitability for wet-milling; however, the results of dissimilar hybrid rank of wet-milled product means for different laboratories and laboratory-dependent correlations among maize quality properties and product yields highlights the challenges in meeting this objective. Several pilot and laboratory wet-milling procedures have been successfully developed to effectively evaluate wet millability $(25,58,61,65$ 68); however, such procedures are constrained by time and cost when rapid and accurate decisions need to be made at the time of selling and buying grain for wet-milling. The results obtained from this corroborative study on wet-milling suggest the need for a new understanding of maize quality properties concerning a better consistency, reproducibility, and sensitivity for wet-milling characteristics, which would provide useful information about a specific hybrid's potential in wet-milling.

In conclusion, the low standard deviations of within-laboratory repeatability and between-laboratory reproducibility obtained from this corroborative study are likely to verify the suitability and reliability of the procedures to measure maize quality properties that are currently used in most grain quality laboratories. Large variation in maize quality properties came from the effects of hybrids and laboratories. The present study may ensure the hybrid effect as a greater source of variation in maize quality and milling properties if variation between laboratories and other sources of the variation, including inadequate standardization, complexity of the procedure, kernel storability, and physical conditions, are effectively controlled. This alludes to the large impact of hybrid selection by end-users during breeding programs. The inconsistent and irreproducible test results between previous studies might be largely attributed to the effects of hybrids and laboratories as well as other uncontrollable factors. For that reason, the recommendation of one test over another predicting end-use characteristics are somewhat suspect. With ongoing efforts to find inheritable, relevant, and consistent criteria for end-use performance, researchers, hybrid seed companies, and milling industries should collaborate to improve the procedures and carefully interpret the results to prevent detrimental effects on breeding programs and the grain industry.
Acknowledgments - Dr. Scott R. Bean of USDA-ARS, Grain Marketing and Production Research Center, Manhattan, KS, is appreciated for his advice and guidance throughout this work. The authors gratefully acknowledge financial support and provided maize samples from the Andersons Endowment administered through the Ohio Agricultural Research and Development Center of The Ohio State University, AgraMarke Quality Grains, Frito Lay Inc., and seed companies for this study.

\section{References}

1. Paulsen, M. R.; Watson, S. A.; Singh, M. Measurement and maintenance of corn quality. In Corn Chemistry and Technology; White, P. J., Johnson, L. A. Eds.; American Association of Cereal Chemists: St. Paul, Minnesota, 2003; Chapter 5, pp. 159-219.

2. Stroshine, R. L.; Kirleis, A. W.; Tuite, J. F.; Bauman, L. F.; Emam, A. Different in grain quality among selected corn hybrids Cereal Foods World. 1986 31:311-316

3. Pomeranz, Y.; Martin, C. R.; Traylor, D. D.; Lai, F. S. Corn hardness determination Cereal Chem. 1984 61:147-150

4. Pomeranz, Y.; Czuchajowska, Z.; Martin, C. R.; Lai, F. S. Determination of corn hardness by the Stenvert hardness tester Cereal Chem. 1985 62:108-112

5. Dorsey-Redding, C.; Hurburgh, C. H.; Johnson, L. A.; Fox, S. R. Relationship among maize quality factors Cereal Chem. 1991 68:602-605

6. Shandera, D. L.; Jackson, D. S.; Johnson, B. E. Quality factors impacting processing of maize dent hybrids Maydica. 1997 42:281-289

7. Vyn, T. J.; Tollenaar, M. Changes in chemical and physical quality parameters of maize grain during three decades of yield improvement Field Crop Res. 1998 59: 135-140

8. Watson, S. A. Description, structure, and composition of the corn kernel. In Corn Chemistry and Technology; White, P. J.; Johnson, L. A. Eds.; American Association of Cereal Chemists: St. Paul, Minnesota, 2003; Chapter 3, pp. 69-106.

9. Kirleis, A. W.; Stroshine, R. L. Effects of hardness and drying air temperature on breakage susceptibility and dry-milling characteristics of yellow dent corn Cereal Chem. 1990 67: 523-528

10. Wu, Y. V.; Bergquist, R. R. Relation of corn grain density to yields of dry-milling products Cereal Chem. 1991 68: 542-544

11. Eyherabide, G. H.; Robutti, J. L.; Borras, F. S. Effect of nearinfrared transmission-based selection on maize hardness and the composition of zeins Cereal Chem. 1996 73: 775-778

12. Dombrink-Kurtzman, M. A.; Knutson, C. A. A study of maize endosperm hardness in relation to amylose content and susceptibility to damage Cereal Chem. 1997 74: 776-780

13. Chandrashekar, A.; Mazhar, H. The biochemical basis and implication of grain strength in sorghum and maize J. Cereal Sci. 1999 30: 193-207

14. Paulsen, M. R.; Hill, L. D. Corn quality factors affecting drymilling performance J. Agric. Eng. Res. 1985 31: 255-263

15. Peplinski, A. J.; Paulsen, M. R.; Bouzaher, A. Physical, chemical, and dry-milling properties of corn of varying density and breakage susceptibility Cereal Chem. 1992 69: 397-400

16. Pan, Z.; Eckhoff, S. R.; Paulsen, M. R.; Litchfield, J. B. Physical properties and dry-milling characteristics of six selected highoil maize hybrids Cereal Chem. 1996 73: 517-520

17. Lee, K. M.; Herrman, T. J.; Bean, S. R.; Jackson, D. S.; Lingenfelser, J. Classification of Dry-milled maize grit yield groups using quadratic discriminant analysis and decision tree algorithm Cereal Chem. 2007 84: 152-161

18. Lee, K. M.; Herrman, T. J.; Lingenfelser, J.; Jackson, D. S. Classification and prediction of maize hardness-associated proper- 
ties by using multivariate statistical analyses J. Cereal Sci. 2005 41: 85-93

19. Youden, W. J.; Steiner, E. H.. Statistical Manual of the AOAC. Youden, W. J.; Steiner, E. H., Eds.; Association of Official Analytical Chemists: Arlington, Virginia, 1975.

20. Association of Official Analytical Chemists. Guidelines for collaborative study procedure to validate characteristics of a method of analysis. J. Assoc. Off. Anal. Chem. 1989, 72: 694-704.

21. USDA. General Information. In Grain Grading Procedures: USDA Federal Grain Inspection Service: Washington DC, 1990; Chapter 1, pp. 15-17.

22. Reichert, R. D.; Tyler, R. T.; York, A. E.; Schwab, D. J.; Tatarynovich, J. E.; Mwasaru, M. A. Description of a production model of the tangential abrasive dehulling device and its application to breeder's samples Cereal Chem. 1986 63: 201-207

23. American Association of Cereal Chemists. AACC Approved Method of the AACC, 10th ed.; AACC: St. Paul, Minnesota, 2000, pp 44-15A.

24. Singh, V.; Batie, C. J.; Rausch, K. D.; Miller, C. Wet-milling and dry-milling properties of dent corn with addition of amylase corn Cereal Chem. 2006 83: 321-323

25. Eckhoff, S. R.; Singh, S. K.; Zehr, B. E.; Rausch, K. D.; Fox, E. J.; Mistry, A. K.; Haken, A. E.; Niu, Y. U.; Zou, S. H.; Buriak, P.; Tumbelson, M. E.; Keeling, P. L. A 100-g laboratory corn wetmilling procedure Cereal Chem. 1996 73: 54-57

26. Wehling, R. L.; Jackson, D. S.; Hopper, D. G.; Ghaedian, A. R. Prediction of wet-milling starch yield from corn by near-infrared spectroscopy Cereal Chem. 1993 70: 720-723

27. SAS User's guide: Statistics, version 9.13 ed.; SAS Institute: Cary, North Carolina, 2004.

28. Thompson, R. A.; Isaacs, G. W. Porosity determinations of grains and seeds with an air-comparison pycnometer Trans. ASAE. 1967 10: 693-696

29. Manoharkumar, B.; Gerstenkorn, P.; Zwingelberg, H.; Bolling, $\mathrm{H}$. On some correlations between grain composition and physical characteritics to the dry-milling performance in maize $J$. Food Sci. Tech. 1978 15: 1-6

30. Peplinski, A. J.; Paulsen, M. R.; Anderson, R. A.; Kwolek, W. F. Physical, chemical, and dry-milling characteristics of corn hybrids from various genotypes Cereal Chem. 1989 66: 117-120

31. Dorsey-Redding, C.; Hurburgh, C. H.; Johnson, L. A.; Fox, S. R. Adjustment of maize quality data for moisture content Cereal Chem. 1990 67: 292-295

32. Zehr, B. E.; Eckhoff, S. R.; Singh, S. K.; Keeling, P. L. Comparison of wet-milling properties among maize inbred lines and their hybrids Cereal Chem. 1995 72: 491-497

33. Haros, M.; Tolaba, M. P.; Suarez, C. Influence of corn drying on its quality for the wet-milling process J. Food Eng. 2003 60: 177-184

34. Brekke, O. L.; Peplinski, A. J.; Griffin, E.L. Jr.; Ellis, J.J. Dry milling of corn attacked by southern leaf blight Cereal Chem. 1972 49: 466-478

35. Delwiche, S. R.; Pierce, R. O.; Chung, O. K.; Seabourn, B. W. Protein content of wheat by near-infrared spectroscopy of whole grain: Collaborative study J. AOAC Int. 1998 81: 587-603

36. Multon, J. L. Basics of moisture measurement in grain. In Uniformity by 2000: An International Workshop on Maize and Soybean Quality; Hill, L. D., Eds; Scherer Communications: Urbana, Illinois, 1991; Chapter 5, pp 35- 67.

37. Paulsen, M. R. Analyzing moisture measurement: Direct moisture reference methods. In Uniformity by 2000: An International Workshop on Maize and Soybean Quality; Hill, L. D., Eds; Scherer Communications: Urbana, Illinois, 1991; pp 391- 399.

38. Hall, G. E.; Hill, L. D. Test weight adjustment based on mois- ture content and mechanical damage of corn kernels Trans. ASAE. 1974 17: 578-579

39. Brown, R. B.; Fulford, G. N.; Daynard, T. B.; Meiering, A. G.; Otten, L. Effect of drying method on grain corn quality Cereal Chem. 1979 56: 529-532

40. Nelson, S. O. Moisture-dependent kernel- and bulk-density relationships for wheat and corn Trans. ASAE. 1980 23: 139-143

41. Pomeranz, Y.; Hall, G. E.; Czuchajowska, Z.; Lai, F. S. Test weight, hardness, and breakage susceptibility of yellow dent corn hybrids Cereal Chem. 1986 63: 349-351

42. Freeman, J. E. Quality factors affecting value of corn for wet milling Trans. ASAE. 1973 16: 671-678

43. USDA-GIPSA. Subpart D - U.S. standards for corn. In Official United States Standards for Grain. USDA Grain Inspection, Packers and Stockyards Administration: Washington DC, 1996.

44. Hlynka, L.; Bushuk, W. The weight per bushel Cereal Sci. Today. 1959 4: 239-240

45. Chung, D. S.; Converse, H. H. Effect of moisture content on some physical properties of grains Trans. ASAE. 1971 14: 612614,620

46. Jennings, S. D.; Myers, D. J.; Johnson, L. A.; Pollak, L. M. Effects of maturity on grain quality and wet-milling properties of two selected hybrids Cereal Chem. 2002 79: 697-702

47. Yuan, J.; Flores, R. A. Laboratory dry-milling performance of white corn: Effect of physical and chemical corn characteristics Cereal Chem. 1996 73: 574-578

48. Robutti, J. L. Maize kernel hardness estimation in breeding by near-infrared transmission analysis Cereal Chem. 1995 72: 632-636

49. Fox, S. R.; Johnson, L. A.; Hurburgh, C. R.; Dorsey-Redding, C. Relations between grain properties to wet-milling characteristics of maize Cereal Chem. 1992 69: 191-197

50. Oomah, B. D.; Reichert, R. D.; Youngs, C. G. A novel, multisample, tangential abrasive dehulling device (TADD) Cereal Chem. 1981 58: 392-395

51. Lawton, J. W.; Faubion, J. M. Measuring kernel hardness using the Tangential Abrasive Dehulling Device Cereal Chem. 1989 66: 519-524

52. Wehling, R. L.; Jackson, D. S.; Hamaker, B. R. Prediction of corn dry-milling quality by near-infrared spectroscopy Cereal Chem. 1996 73: 543-546

53. Brekke, O. L. Dry milling artificially dried corn; roller-milling of degerminator stock at various moisture Cereal Sci. Today. 1970 15: 37-42

54. Rutledge, J. H.. The value of corn quality to the dry miller. In Proceedings of 1977 Corn Quality Conference; Department of Agricultural Economics University of Illinois: Urbana, Illinois, 1978; AE-4454, pp. 158-162.

55. Mestres, C.; Louis-Alexandre, A.; Matencio, F.; Lahlou, A. Drymilling properties of maize Cereal Chem. 1991 68: 51-56

56. Pomeranz, Y.; Czuchajowska, Z. Laboratory tests to predict the commercial yield of flaking or large grits in dry corn milling Cereal Chem. 1987 52: 830-832

57. Wu, Y. V. Corn hardness as related to yield and particle size of fractions from a micro hammer-cutter mill Cereal Chem. 1992 69: 343-347

58. Singh, S.; Johnson, L. A.; Pollak, L. M.; Fox, S. R.; Bailey, T. B. Comparison of laboratory and pilot-plant corn wet-milling procedures Cereal Chem. 1997 74: 40-48

59. Haros, M.; Suarez, C. Effect of drying, initial moisture and variety in corn wet milling J. Food Eng. 1997 34: 473-481

60. Rausch, K. D.; Fox, E. J.; Eckhoff, S. R. Wet milling characteristics of high oil corn hybrids Starch/Starke. 1999 51: 411-415 
61. Vignaux, N.; Fox, S. R.; Johnson, L. A. A 10-g laboratory wetmilling procedure for maize and comparison with larger scale laboratory procedures Cereal Chem. 2006 83: 482-490

62. Singh, S. K.; Johnson, L. A.; Pollak, L. M.; Hurburgh, C. R. Compositional, physical, and wet-milling properties of accessions in Germplasm Enhancement of Maize project Cereal Chem. 2001 78: 330-335

63. Mistry, A. H.; Wu, X.; Eckhoff, S. R.; Litchfield, J. B. Wet-milling characteristics of high-temperature, high-humidity maize Cereal Chem. 1993 70: 360-361

64. Weller, C. L.; Paulsen, M. R.; Steinberg, M. P. Correlation of starch recovery with assorted quality factors of four corn hybrids Cereal Chem. 1988 65: 392-397
65. Watson, S. A.; Williams, C. B.; Wakely, R. D. Laboratory steeping used in a wet-milling research program Cereal Chem. 1951 28: 105-115

66. Anderson, R. A. A pilot plant for wet milling Cereal Sci. Today. 1957 2: 78-80

67. Steinke, J. D.; Johnson, L. A.; Wang, C. Steeping maize in the presence of multiple enzymes. II. Continuous countercurrent steeping Cereal Chem. 1991 68: 7-12

68. Eckhoff, S. R.; Rausch, K. D.; Fox, E. J.; Tso, C. C.; Wu, X.; Pan, Z.; Buriak, P. A laboratory wet-milling procedure to increase reproducibility and accuracy of product yield Cereal Chem. 1993 70: 723-727 